\title{
REVISÃO BIBLIOGRÁFICA PARA ADEQUAÇÃO DE UMA METODOLOGIA DE DETECÇÃO DO MICROPLÁSTICO NA GOMA E ÁGUAS RESIDUÁRIAS RESULTANTES DO PROCESSO DE BENEFICIAMENTO DA MANDIOCA
}

\section{BIBLIOGRAPHIC REVIEW TO ADEQUATE A METHODOLOGY FOR DETECTION OF MICROPLASTICS IN GUM AND WASTEWATER RESULTING FROM THE CASSAVA BENEFIT PROCESS}

\section{Marina Pereira Ribeiroa, Mariana Mendes Costa Oliveira ${ }^{a}$, Nayara de Santana Santos ${ }^{a}$, Alessandra Cristina Silva Valentima}

marinapereiraribeiro98@hotmail.com, marianamendesesa@gmail.com, nayara santana09@hotmail.com, alessandra@ufrb.com

\author{
aUniversidade Federal do Recôncavo da Bahia (UFRB)
}

Submissão: 08 de novembro de 2020 Aceitação: 19 de novembro de 2020

\section{Resumo}

O Brasil apresenta um alto cultivo de raiz de mandioca, que além de ser usada para consumo in natura, possui diversos produtos derivados, dentre os quais se destacam a farinha e a goma. O processo de beneficiamento da mandioca gera um subproduto denominado manipueira, um efluente líquido considerado uma substância poluidora, por conter níveis de toxicidade superiores aos do esgoto doméstico. Devido ao uso de materiais plásticos no processo produtivo de derivados da mandioca, existe a possibilidade da presença de microplásticos tanto nos produtos quanto no referido subproduto. Este estudo teve como objetivo definir metodologias mais adequadas para a detecção de microplásticos em amostras da goma e da manipueira. $\mathrm{O}$ método para alcançar este intento foi uma revisão bibliográfica das metodologias utilizadas para águas residuárias e sedimentos. A revisão dessas metodologias resultou em uma adaptação, que este estudo traz como uma proposta de um procedimento analítico que envolve etapas de amostragem, extração, quantificação e controle da qualidade. Espera-se que, após a sua validação através de ensaios interlaboratoriais, a metodologia proposta mostre altas eficiências de detecção de microplásticos, contribuindo para avanços científicos na área.

Palavras-chave: Micropartículas de plástico; Metodologia; Mandioca; Manipueira

\section{Abstract}

Brazil has a high cultivation of cassava root, which in addition to being used for fresh consumption has several derivative products, among which flour and gum stand out. The process of processing cassava generates a by-product called cassava wastewater, a liquid effluent considered a polluting substance, as it contains higher levels of toxicity than domestic sewage. Due to the use of plastic materials in the production process of cassava derivatives, there is the possibility of the presence of microplastics both in the products and in the referred byproduct. This study aimed to define more appropriate methodologies for the detection of microplastics in gum and cassava wastewater samples. The method to achieve this goal was a literature review of the methodologies used for wastewater and sediments. The revision of these methodologies resulted in an adaptation, which this study brings as a proposal for an analytical procedure that involves sampling, extraction, quantification and quality control steps. It is expected that, after its validation through interlaboratory tests, the proposed methodology will show high efficiency of detection of microplastics, contributing to scientific advances in the area.

Keywords: Plastic microparticles; Methodology; Cassava; Cassava Wastewater 


\section{INTRODUÇÃO}

Desde a descoberta do plástico até os dias atuais, a utilização desse material tem se tornado cada vez mais frequente e indispensável nos mais diversos setores da sociedade. Isso se deve às suas características atrativas, como maleabilidade, baixo custo e durabilidade (CORRÊA et al., 2019; PIATTI; RODRIGUES, 2005). Os plásticos são definidos como materiais constituídos por ligações moleculares orgânicas, resultado da síntese ou transformação de produtos naturais, e são compostos por macromoléculas, que, por sua vez, são constituídas de elementos individuais chamados de polímeros (AKCELRUD, 2007; MICHAELI et al., 2018). Apesar dos diversos benefícios que esse material oferece, existem diversos problemas ambientais decorrentes, principalmente, do uso e descarte inadequado (SILVA et al., 2013).

Como enunciado na Lei da Conservação de Massa, formulada por Antoine Laurent Lavoisier em 1789: "Na natureza, nada se perde, nada se cria, tudo se transforma". O que um dia era matéria-prima e se tornou plástico, quando descartado, no processo de decomposição, se transforma em micropartículas. As micropartículas resultantes do processo de degradação do plástico são denominadas microplásticos (MP). Devido aos estudos sobre esse material serem recentes, ainda não existe uma padronização do tamanho dessas partículas. Alguns autores consideram aceitáveis valores inferiores a $20 \mathrm{~mm}$ (HIDALGO-RUZ et al., 2012). Enquanto outros entendem que as micropartículas devem pertencer a escala micrométrica, adotando-se valores inferiores a 1 mm (CLAESSENS et al., 2013). Apesar das discordâncias encontradas na literatura em relação à classificação do tamanho dessas micropartículas (COLE et al., 2011; HIDALGORUZ et al., 2012), em 2009, no Workshop de Pesquisa Internacional da Administração Oceânica e Atmosférica Nacional (NOAA) sobre a ocorrência, os efeitos e o destino dos detritos marinhos, foi acordado e assumido formalmente que essas partículas plásticas são de tamanhos iguais ou menores que $5 \mathrm{~mm}$ (ARTHUR; BAKER; BAMFORD, 2009; CESA, 2017).

Dependendo da sua origem, os MP podem ser divididos em duas categorias: os primários e os secundários. Os primários são produzidos para serem utilizados como matéria-prima para diferentes aplicações, podendo ser identificados em produtos de higiene pessoal, como sabonete e creme dental; enquanto os secundários são resultantes da utilização de objetos plásticos maiores, que podem ser degradados por diversos fatores, como a radiação ultravioleta (AUTA et al., 2018; GOUVEIA, 2018; HOELLEIN et al., 2017; IVAR DO SUL; COSTA, 2014; NAPPER et al., 2015).

Atualmente todos os ecossistemas da Terra estão contaminados com MP (PRATA et al., 2019). As atividades desenvolvidas em setores terrestres, destacando-se a agricultura, construção civil, turismo, e em setores marinhos como pesca, aquicultura e navegação, além dos produtos consumidos individualmente, são responsáveis por algum tipo liberação de MP no meio ambiente (CESA, 2017). Um estudo realizado por Cox e colaboradores (2019) avaliou a concentração de partículas de MP no ar e em alimentos e bebidas consumidos por estadunidenses. Pelos dados encontrados com base na dieta alimentar em idades variáveis (crianças e adultos) e sexo (masculino e feminino), o estudo estimou que a ingestão anual variou de 39 mil a 52 mil partículas, com possibilidade em aumentar de 74 mil a $121 \mathrm{mil}$ quando considerada a quantidade absorvida por inalação. De acordo com Cox e colaboradores (2019), essas estimativas do consumo americano de MP foram provavelmente subestimações drásticas e o consumo anual de MP pode ultrapassar várias centenas de milhares. As elevadas taxas de MP consumidos ilustram a magnitude do problema. Apesar dos avanços nos estudos, ainda não se pode prever os efeitos do MP para saúde humana (ALVAREZ et al., 2020; THOMPSON et al., 2004). Mas é certo que se trata de um problema ambiental e de saúde pública grave, que precisa ser estudado urgentemente para que sejam criadas medidas de controle e mitigação.

Como constatado em vários estudos, os MP podem ser encontrados em efluentes domésticos (FERRARI, 2019; GOUVEIA, 2018; MURPHY et al., 2016; MAGNUSSON; NORÉN, 2014; ZIAJAHROMI et al., 2017). Isso se deve tanto pela disposição inadequada dos resíduos plásticos, quanto pelo uso de cosméticos e produtos que possuem polímeros em sua composição, tais como, fibras de roupas, escovas de dente, sabonetes, tintas, entre outros (GOUVEIA, 2018; ZIAJAHROMI et al., 2017). Os MP também estão presentes em efluentes provenientes de atividades industriais, como determinado por Wang e colaboradores (2020) em estudo que analisou efluentes industriais, agrícolas e aquícolas e que 
detectou a ocorrência desse poluente. A presença dessas partículas em efluentes é preocupante, pois elas são pequenas o suficiente para passarem pelas etapas de tratamento, até mesmo no nível terciário, e acabam sendo lançadas no corpo receptor (GOUVEIA, 2018; MURPHY et al., 2016). A adsorção dessas partículas pelos seres vivos pode afetar a saúde conferindo-lhes efeitos tóxicos letais. Também provocam a poluição e a contaminação ambiental, desequilibrando 0 ecossistema (GOUVEIA, 2018; MAGRINI et al., 2012).

O MP pode ser encontrado em diferentes águas residuais. $\mathrm{A}$ água efluente do processamento da mandioca para obtenção de farinha de mesa é um exemplo. A mandioca é uma matéria-prima de importância econômica e social em diversas partes do território brasileiro (MODESTO JÚNIOR; ALVES, 2016). A estimativa da produção brasileira de mandioca em 2019 foi 20,2 milhões de toneladas (IBGE, 2019). A raiz de mandioca pode ser utilizada na sua forma in natura e na geração diversificada de produtos e subprodutos; a título de exemplo: a farinha de mandioca, fécula, tucupi, entre outros (BEZERRA, 2006). Os principais derivados da mandioca são a farinha e a goma de mandioca, consumidas em larga escala no país (SEBRAE, 2012).

O processo de beneficiamento da mandioca para produção da farinha e outros produtos pode ser realizado em fecularia, de forma industrial, como também de forma tradicional em locais popularmente conhecidos como "casas de farinha", um ambiente de trabalho coletivo com características simples e geralmente constituído por equipamentos rústicos. Em relação ao controle de qualidade, nas fecularias existem protocolos que garantem a qualidade do produto final, segurança e manutenção dos equipamentos, bem como todo o controle do material de consumo utilizado; já em casas de farinha, onde o processo é artesanal, não existem esses tipos de procedimentos. Apesar das diferenças tecnológicas entre a indústria e a casa de farinha, as etapas básicas do processamento são as mesmas: colheita, transporte, descascamento, lavagem, trituração, prensagem, esfarelamento, torrefação, classificação e embalagem (FIALHO; VIEIRA, 2013).

Após a colheita, as raízes de mandioca são armazenadas e transportadas para o local de produção, onde passam pelo processo de lavagem e remoção da casca externa. Na etapa de trituração, as raízes passam por um ralador e são transformadas em massa. Essa massa ralada, em casas de farinha, geralmente é colocada em recipiente plástico e posteriormente é acondicionada em sacos de náilon e comprimida na prensa de madeira para remoção do líquido, chamado de manipueira (LIMA, 2010; PENICHE, 2014; SILVEIRA, 2006). É importante salientar que os sacos de náilon são reutilizados várias vezes e só são substituídos quando se rompem. Além da degradação causada pela pressão exercida no processo de prensagem e a reutilização do material, outros fatores podem influenciar na vida útil dos sacos plásticos, como a lavagem para a higienização e exposição ao sol para secagem.

$O$ processo de prensagem em fecularias é diferente, pois não são utilizados sacos de náilon e os equipamentos são de inox, o único contato que pode ocorrer é por meio de bandejas plásticas. A prensagem, tanto no ambiente industrial quanto na forma tradicional, resulta em blocos de massa compactados, sendo necessário o esfarelamento, que consiste na desintegração dos blocos por meio de equipamentos. Após o esfarelamento, a massa é encaminhada para torrefação, processo no qual ela perde umidade. Em seguida, para separação e classificação do produto, é feito 0 peneiramento em peneiras padronizadas de diferentes aberturas, obtendo-se farinhas de diferentes granulometrias (SOUZA et al., 2005). Por último, a farinha de mandioca é armazenada em sacos de náilon (BEZERRA, 2006).

A goma de mandioca, também conhecida como fécula, polvilho doce e amido, é definida como um carboidrato que se apresenta como um pó branco, inodoro e sem sabor (ARIENTE et al., 2005). A produção da goma nas casas de farinha é feita de modo tradicional e em paralelo com a produção de farinha. A manipueira extraída na prensagem é colocada em decantação e, após certo período de tempo, a goma é sedimentada. Retira-se então a parte líquida (manipueira) e acrescenta-se água em volume suficiente para cobrimento da goma; a solução é misturada, e repete-se o processo de decantação e remoção do líquido. Esse processo de adição de água, mistura e remoção do líquido sobrenadante é chamado de lavagem da goma e é feito em média três vezes. Após lavagem, a goma é encaminhada para secagem. Como resultado, obtêm-se blocos sólidos de goma, que passam por um triturador ou peneiras para se desintegrarem.

$\mathrm{Na}$ manipulação da mandioca são gerados resíduos sólidos e líquidos. A manipueira é o resíduo líquido extraído da massa ralada durante 
a prensagem. É uma substância com grande potencial poluidor, pois apresenta grande quantidade de carga orgânica, sendo 25 vezes mais poluente que o esgoto doméstico (SANTOS et al., 2012). Segundo Camili (2007), a manipueira apresenta na sua composição açúcares, proteína, sais, linamarina, entre outros. A linamarina é a responsável pela toxicidade da manipueira, por se tratar de um glicosídeo cianogênico proveniente do ácido cianídrico (HCN) (BRANCO, 1979; GONZAGA et al., 2007). Para minimizar os impactos oriundos da manipueira, é possível utilizá-la de forma sustentável (CAMILI, 2007). Além de ser uma substância nociva à saúde humana e animal caso seja ingerida, o descarte incorreto desse material pode acarretar prejuízos ao meio ambiente (WOSIACKI; CEREDA, 2002). E além dos impactos associados à toxicidade da manipueira e ao seu descarte inadequado, o processo de beneficiamento da mandioca nos alerta para a possibilidade de haver contaminação por MP. Em um trabalho acadêmico realizado por Silva e colaboradores (2015), no qual foram estudadas as etapas básicas de produção da farinha de mandioca em casas de farinha, foi descrito o uso de sacos de náilon no processo de fabricação e de sacos plásticos para embalagem. A popularidade da utilização de sacos plásticos na fase de embalagem dos produtos pela indústria alimentícia é fortemente influenciada pela durabilidade do material e a necessidade de preservação do produto (CESA, 2017). O uso de sacos de náilon no processo de produção da farinha de mandioca é uma prática que requer atenção especial devido à possibilidade de liberação de MP tanto na manipueira quanto na goma, e esta é um produto comestível.

Além dos efeitos adversos causados pelas próprias partículas, os MP podem conter substâncias tóxicas aos organismos, como também absorver outras substâncias nocivas e até micro-organismos (DERRAIK, 2002; GOUVEIA, 2018; SILVA; SILVA, 2019). Como afirmam Olivatto e colaboradores (2018) na literatura científica brasileira, o estudo sobre MP é recente e tem se concentrado, em grande parte, no ambiente marinho. Diante da problemática de que o MP pode estar presente em diferentes meios, surge a necessidade de análise e monitoramento desse poluente. Tendo em vista a realidade das casas de farinha, nas quais é possível encontrar essas partículas devido ao processo de beneficiamento da mandioca, o objetivo deste trabalho foi definir metodologias confiáveis que possibilitem a deteç̧ão de MP na manipueira e na goma de mandioca.

\section{MATERIAIS E MÉTODOS}

Este estudo consiste em uma revisão bibliográfica realizada por meio de consultas em livros e trabalhos acadêmicos disponíveis no meio científico. A coleta de dados foi feita nas bases eletrônicas: periódicos da Coordenação de Aperfeiçoamento de Pessoal de Nível Superior (Capes), Scientific Electronic Library Online (Scielo) e Google Scholar. A escolha dos artigos foi feita a partir da leitura dos títulos, resumos e referências, sendo selecionados os que melhor abordassem o tema proposto. O estudo foi realizado no período de agosto de 2019 a outubro de 2020.

Um dos critérios de escolha das metodologias tomadas como base para uma revisão e a criação de uma nova proposta foi o período de sua publicação, todas as escolhidas foram publicadas nesses últimos dez anos (2010 a 2020). Foram selecionadas dez metodologias para revisão dos métodos. A construção de uma proposta metodológica foi feita a partir da leitura e comparação dos trabalhos selecionados. Visando buscar melhor eficiência para os testes futuros, foi investigado em quais meios tinha sido possível identificar a presença de MP e quais deles se assemelhavam quanto aos aspectos físicoquímicos em relação à manipueira e à goma de mandioca (Fluxograma 1).

Diante da possibilidade de se encontrar MP na manipueira e na goma de mandioca, foi feito um levantamento sobre o processamento dessa raiz em casas de farinha, onde se utilizam sacos de náilon e materiais plásticos tanto na produção do alimento quanto no seu beneficiamento, conforme ilustrado na Figura 1.

\section{RESULTADOS E DISCUSSÕES}

O crescente consumo mundial de plástico, com o consequente aumento de seus resíduos, e a contaminação dos ecossistemas contribuíram para expansão de estudos que visam monitorar o comportamento e os efeitos adversos do MP no meio ambiente (HOELLEIN et al., 2017) e os efeitos na saúde humana. Apesar dos avanços nas pesquisas sobre MP, uma das dificuldades associadas à sua detecção e extração em diferentes amostras é a falta de uma metodologia padronizada. A não padronização das 
metodologias interfere diretamente na confiabilidade dos resultados obtidos, visto que diferentes métodos podem fornecer resultados incompatíveis (LÖDER; GERDTS, 2015). Com isso, surge a necessidade de realização de novas pesquisas e testes laboratoriais para que avanços nessa área de estudo possam ser alcançados.

\section{Fluxograma 1 - Identificação de MP em diferentes meios}

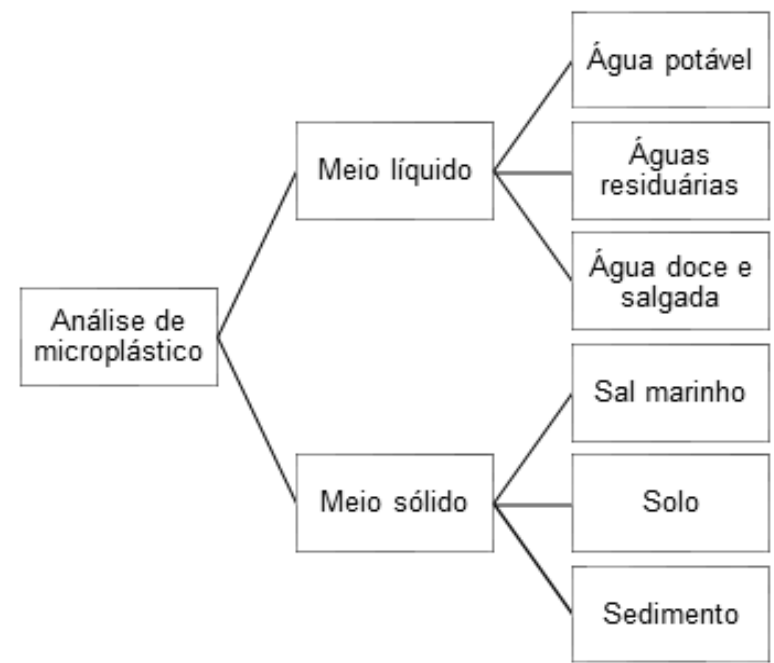

Fonte: Autoras (2020).

Figura 1 - Registro fotográfico de algumas etapas do processamento de mandioca que utilizam sacos de náilon e materiais plásticos em duas casas de farinha localizadas na zona rural do município de Cruz das Almas, Bahia
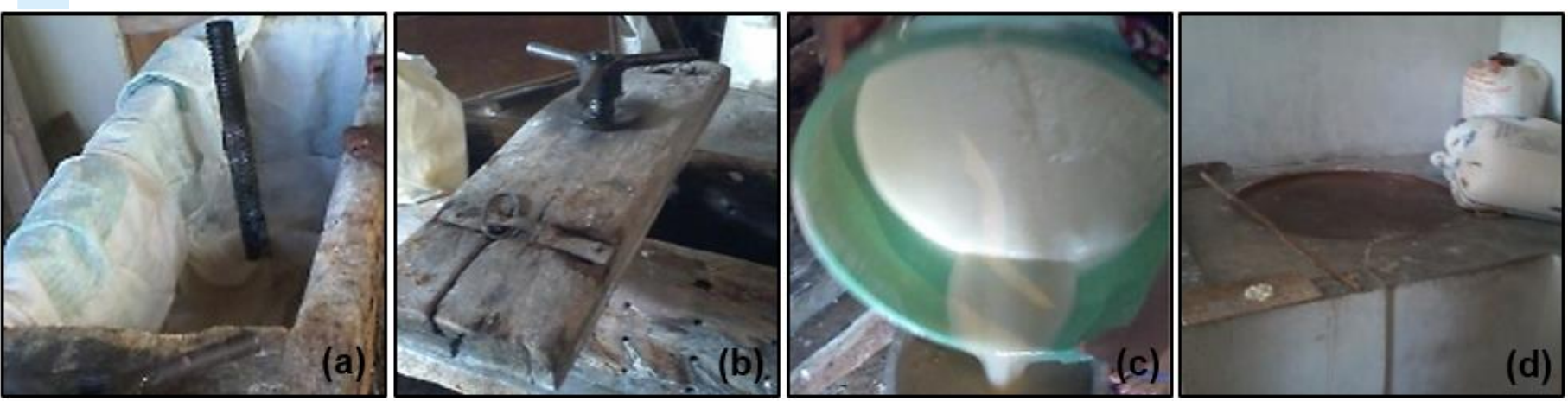

(a) Sacos de náilon usados para forrar a prensa de madeira; (b) Prensa de madeira e saco de náilon ao fundo com goma;

(c) Separação da goma de mandioca decantada da manipueira em recipiente plástico; e (d) Farinha armazenada em sacos de náilon na lateral do forno onde foi torrada.

Fonte: Acervo pessoal (2015 e 2016).

\section{Características da manipueira}

Tendo em vista a caracterização da manipueira descrita na Tabela 1, pode-se observar que esse efluente contém elevados valores de cianeto, nitrogênio, carbono, potássio, dentre outros elementos químicos, apresentando características que se assemelham a um efluente industrial. Essa semelhança também está associada ao seu elevado potencial poluidor. Além disso, a presença excessiva de sólidos sedimentáveis (goma) na manipueira contribuiu 
para que se buscassem metodologias para identificação de MP em amostras aquosas e sedimentos, pelo grau de similaridade que apresentam com o objeto de estudo.

\section{Metodologias selecionadas}

Para construção do método de detecção de MP na manipueira e na goma de mandioca, foram utilizadas referências da literatura nas quais os materiais analisados se assemelham em alguns aspectos ao objeto de estudo. Dessa forma, para a manipueira, que se trata de um efluente líquido, foram selecionados os estudos que analisaram a presença de MP em água e esgoto. Enquanto que para a goma de mandioca, que apresenta características sólidas e boa sedimentabilidade, foram utilizadas as metodologias aplicadas em sedimentos.

Tendo em vista as características da manipueira e da goma, para a realização da análise de MP é necessário utilizar algum agente químico que consiga digerir a matéria orgânica.

No Quadro 1, encontram-se as metodologias selecionadas para a elaboração da proposta objeto deste estudo. Também foram utilizadas a revisão técnica realizada por Hanvey e colaboradores (2017) e a coletânea de metodologias apresentada por Masura colaboradores (2015).

\section{Etapas para identificação de MP}

Foram identificados os processos mais utilizados disponíveis na literatura e estabelecidas as principais etapas de análise, que correspondem desde a amostragem até a quantificação da presença de MP na amostra. A descrição da metodologia poderá seguir as etapas apresentadas no Fluxograma 2.

Tabela 1 - Composição média da manipueira segundo diferentes autores

\begin{tabular}{l|c|c|c|c|c|c|c|c|c}
\hline Variáveis & $\begin{array}{c}\text { LAMO e } \\
\text { MENEZES } \\
(\mathbf{1 9 7 9 )}\end{array}$ & $\begin{array}{c}\text { CABELLO } \\
(\mathbf{1 9 9 1 )}\end{array}$ & $\begin{array}{c}\text { CEREDA } \\
(\mathbf{1 9 9 4 )}\end{array}$ & $\begin{array}{c}\text { PARIZOTTO } \\
(\mathbf{1 9 9 9 )}\end{array}$ & $\begin{array}{c}\text { BARANA } \\
(\mathbf{2 0 0 0 )}\end{array}$ & $\begin{array}{c}\text { FEIDEN } \\
(\mathbf{2 0 0 1 )}\end{array}$ & $\begin{array}{c}\text { PINTO e } \\
\text { CABELL(2011) }\end{array}$ & $\begin{array}{c}\text { CREMONEZ } \\
\text { et al. (2013) }\end{array}$ & $\begin{array}{c}\text { NEVES et } \\
\text { al. (2014) }\end{array}$ \\
\hline $\mathrm{pH}$ & 4,40 & 6,40 & 4,10 & 7,06 & - & 6,18 & 6,63 & $5,3 \pm 0,7$ & 4,14 \\
\hline $\mathrm{ST}^{*}$ & $56.460,00$ & 939,00 & 628,00 & 14,80 & 5,54 & 9,20 & 6,98 & $3800 \pm 1305$ & - \\
\hline $\mathrm{SV}^{*}$ & - & - & - & - & 4,76 & 6,40 & 3,86 & - & - \\
\hline $\mathrm{DQO}^{*}$ & $51.200,00$ & $46.000,00$ & $6.365,00$ & $11.363,00$ & 62,30 & $11.484,00$ & $14.300,00$ & $4800 \pm 0,7$ & - \\
\hline $\mathrm{DBO}^{*}$ & $34.300,00$ & $34.300,00$ & - & - & - & - & $12.215,00$ & $1680 \pm 755$ & - \\
\hline $\begin{array}{l}\text { Cianeto } \\
{ }^{*}\end{array}$ & - & $130.00,00$ & 444,00 & - & 112,20 & 19,00 & 12,60 & $3,5 \pm 0,5$ & 257,20 \\
\hline $\mathrm{N}^{*}$ & $1.150,00$ & $2.646,00$ & - & - & 1242,00 & 420,00 & 360,00 & $105 \pm 16$ & - \\
\hline $\mathrm{P}^{*}$ & - & 401,00 & 160,84 & 41,00 & 325,00 & 74,00 & 42,00 & - & 201,50 \\
\hline $\mathrm{K}^{*}$ & - & - & - & $1.305,00$ & 1972,00 & $1.215,00$ & $1.286,00$ & - & $4.011,00$ \\
\hline
\end{tabular}

*Valores em mg: pH: potencial hidrogeniônico; SV: sólidos voláteis; ST: sólidos totais; DQO: demanda química de Oxigênio; DBO: demanda bioquímica de oxigênio; N: nitrogênio; P: fósforo; K: potássio.

Fonte: Autoras (2020).

\section{Fluxograma 2 - Etapas de análise de MP}

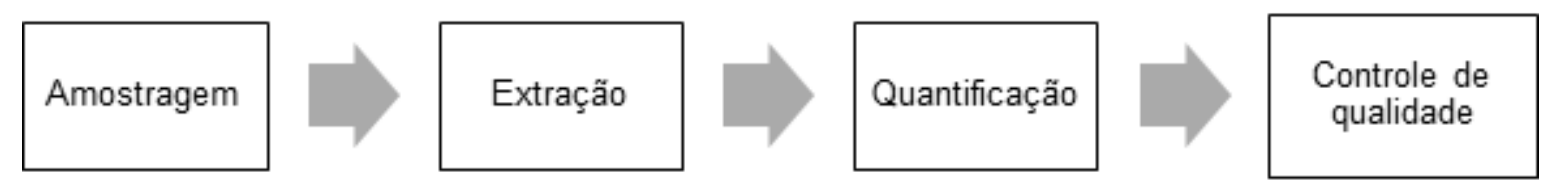

Fonte: Autoras (2020). 
Quadro 1 - Principais metodologias selecionadas neste estudo

\begin{tabular}{|c|c|c|c|}
\hline $\begin{array}{c}\text { Material } \\
\text { analisa } \\
\text { do }\end{array}$ & Metodologia & Principais resultados & $\begin{array}{l}\text { Refe } \\
\text { rên } \\
\text { cia }\end{array}$ \\
\hline $\begin{array}{l}\text { Afluente e } \\
\text { efluente em } \\
\text { estações de } \\
\text { tratamento } \\
\text { de águas } \\
\text { residuais }\end{array}$ & $\begin{array}{l}\text { Tratamento laboratorial das amostras, com solução de cloreto } \\
\text { de sódio ( } \mathrm{NaCl} \text { ) ou hidróxido de potássio }(\mathrm{KOH}) \text {, para digestão } \\
\text { da matéria orgânica; filtração; observação dos filtros com lupa } \\
\text { e seleção de MP (fragmentos e fibras); espectroscopia de } \\
\text { infravermelho com transformada de Fourier em modo de } \\
\text { reflectância total atenuada, com vista à determinação dos } \\
\text { polímeros presentes; e tratamento estatístico, realizado com } \\
\text { o software. }\end{array}$ & $\begin{array}{l}\text { Conseguiu quantificar e categorizar os } \\
\text { MP, como fibras e fragmentos, bem } \\
\text { como determinou suas dimensões e } \\
\text { cor no afluente bruto das estações de } \\
\text { tratamento de águas residuais. }\end{array}$ & $\begin{array}{l}\text { Gouveia } \\
\text { (2018) }\end{array}$ \\
\hline $\begin{array}{l}\text { Afluente e } \\
\text { efluente em } \\
\text { estações de } \\
\text { tratamento } \\
\text { de águas } \\
\text { residuais }\end{array}$ & $\begin{array}{l}\text { Filtração das amostras; secagem em estufa e pesagens; } \\
\text { tratamento com peróxido de hidrogênio; filtração novamente; } \\
\text { separação por densidade com uso de solução (NaCl); e } \\
\text { análise e categorização visual dos MP na lupa microscópica. }\end{array}$ & $\begin{array}{l}\text { Foi observado que o tipo de MP mais } \\
\text { presente no esgoto bruto e tratado são } \\
\text { as fibras sintéticas que compõem os } \\
\text { tecidos e são liberadas por lavagens } \\
\text { residenciais. Também foi observado a } \\
\text { presença de MP secundários } \\
\text { classificados como fragmentos, } \\
\text { coloridos e incolores, tanto em esgoto } \\
\text { bruto quanto no tratado. }\end{array}$ & $\begin{array}{l}\text { Ferrari } \\
(2019)\end{array}$ \\
\hline $\begin{array}{l}\text { Águas } \\
\text { residuais }\end{array}$ & $\begin{array}{l}\text { Construção de dispositivo de coleta; secagem na estufa a } \\
90^{\circ} \mathrm{C} \text { e tratamento com peróxido de hidrogênio a } 30 \%\left(\mathrm{H}_{2} \mathrm{O}_{2}\right) ; \\
\text { agitação a } 60^{\circ} \mathrm{C} \text { até a evaporação do } \mathrm{H}_{2} \mathrm{O}_{2} ; \text { separação por } \\
\text { densidade com adição de iodeto de sódio (Nal); filtração; } \\
\text { aplicação do corante Rosa-Bengala, que mancha partículas } \\
\text { naturais e não plásticas; secagem a } 60^{\circ} \mathrm{C} \text {; análise em } \\
\text { microscópio de dissecação e remoção das partículas coradas; } \\
\text { classificação e contagem dos MP; caracterização dos MP } \\
\text { corados por meio de espectroscopia } \mathrm{FT}-\mathrm{IR} \text {. Também foram } \\
\text { realizados experimentos de validação, para confirmar a } \\
\text { eficiência do método de coloração, e realizou-se análise em } \\
\text { amostra de efluentes com adição de partículas microplásticas. }\end{array}$ & $\begin{array}{l}\text { Médias de } 0,28,0,48 \text { e } 1,54 \mathrm{MP} \text { por } \\
\text { litro de efluente final foram } \\
\text { encontradas no efluente terciário, } \\
\text { secundário e primário, } \\
\text { respectivamente. Este estudo sugere } \\
\text { que, embora baixas concentrações de } \\
\text { MP sejam detectadas em efluentes de } \\
\text { águas residuais, as ETARs ainda têm } \\
\text { o potencial de atuar como uma via de } \\
\text { liberação de MP, dados os grandes } \\
\text { volumes de efluentes lançados no } \\
\text { ambiente aquático. }\end{array}$ & $\begin{array}{l}\text { Ziajahro } \\
\text { mi et al. } \\
\text { (2017) }\end{array}$ \\
\hline $\begin{array}{l}\text { Águas } \\
\text { residuais } \\
\text { domésticas, } \\
\text { industriais, } \\
\text { agrícolas e } \\
\text { aquícolas }\end{array}$ & $\begin{array}{l}\text { Tratamento enzimático das amostras; digestão com peróxido } \\
\text { de hidrogênio }\left(\mathrm{H}_{2} \mathrm{O}_{2}\right) \text {; separação por densidade; } \\
\text { categorização por espectroscopia micro-Raman; classificação } \\
\text { por forma, tamanho e cor. Na China, foram analisados } \\
\text { afluentes e efluentes de } 9 \text { ETARs e } 5 \text { ETARs industriais, } \\
\text { águas residuais de } 10 \text { fábricas industriais e de } 4 \text { fazendas de } \\
\text { gado. Além disso, } 4 \text { tanques de peixes foram investigados. }\end{array}$ & $\begin{array}{l}\text { Os resultados mostraram não haver } \\
\text { diferenças significativas na } \\
\text { abundância de MP entre efluentes ou } \\
\text { águas residuais de diferentes fontes, } \\
\text { indicando que todos constituem fontes } \\
\text { de poluição de MP. }\end{array}$ & $\begin{array}{l}\text { Wang et } \\
\text { al. } \\
(2020)\end{array}$ \\
\hline $\begin{array}{l}\text { Água } \\
\text { superficial de } \\
\text { um lago }\end{array}$ & $\begin{array}{l}\text { Tratamento das amostras com peróxido de hidrogênio }\left(\mathrm{H}_{2} \mathrm{O}_{2}\right) \\
\text { a } 30 \% \text {; diluição da amostra com água destilada e filtrada } \\
\text { através de um papel de filtro, sob vácuo; o papel de filtro foi } \\
\text { colocado em uma placa de Petri e analisado através de } \\
\text { microscopia eletrônica de varredura; classificação dos MP em } \\
\text { seis classes, de acordo com suas características morfológicas } \\
\text { (como cor, estrutura da superfície e forma). }\end{array}$ & $\begin{array}{l}80 \% \text { dos MP encontrados tinham um } \\
\text { tamanho de }<2 \mathrm{~mm} \text {. Polietileno } \\
\text { tereftalato e polipropileno foram os } \\
\text { tipos dominantes de polímero de MP } \\
\text { analisados. }\end{array}$ & $\begin{array}{l}\text { Wang et } \\
\text { al. } \\
(2017)\end{array}$ \\
\hline Sedimento & $\begin{array}{l}\text { Coleta, secagem e peneiramento das amostras; tratamento } \\
\text { com peróxido de hidrogênio }\left(\mathrm{H}_{2} \mathrm{O}_{2}\right) \text { a } 30 \% \text {; secagem } \\
\text { novamente; extração das partículas de microplásticos por } \\
\text { meio de separação por densidade em solução de cloreto de } \\
\text { zinco }\left(\mathrm{ZnCl}_{2}\right) \text {; agitação; tratamento em banho ultrassônico; }\end{array}$ & $\begin{array}{l}1,4 \% \text { das partículas visualmente } \\
\text { semelhantes aos MP eram de origem } \\
\text { de polímero sintético. O estudo } \\
\text { comprova a necessidade de medições }\end{array}$ & $\begin{array}{l}\text { Löder e } \\
\text { Gerdts } \\
\text { (2015) }\end{array}$ \\
\hline
\end{tabular}




\begin{tabular}{|c|c|c|c|}
\hline & $\begin{array}{l}\text { armazenamento para sedimentação das partículas de areia; } \\
\text { filtração das partículas de microplásticos que se acumularam } \\
\text { na superfície da solução de cloreto de zinco; secagem dos } \\
\text { filtros; contagem das partículas sob o microscópio; } \\
\text { classificação das partículas (granulares/esféricos, fragmentos } \\
\text { e fibrosos); espectroscopia de infravermelho com } \\
\text { transformada micro-Fourier (FTIR) baseada em matriz de } \\
\text { plano focal (FPA). }\end{array}$ & $\begin{array}{l}\text { espectroscópicas, como FTIR para } \\
\text { análise confiável de MP. }\end{array}$ & \\
\hline Sedimento & $\begin{array}{l}\text { Construção de um dispositivo para extração dos MP; redução } \\
\text { do volume da amostra por elutriação, separação por } \\
\text { densidade com o uso de solução de iodeto de sódio (Nal); } \\
\text { coleta do material na peneira; extração com Nal; transferência } \\
\text { dos sólidos para um tubo de centrífuga com solução de Nal; } \\
\text { agitação vigorosa (manual) e centrifugação; filtração a vácuo } \\
\text { em um filtro de membrana; repetição da extração de Nal, duas } \\
\text { a três vezes para garantir que todas as partículas de plástico } \\
\text { sejam removidas da amostra de sedimento; inspeção visual } \\
\text { do filtro com um microscópio de dissecção; e validação do } \\
\text { método. }\end{array}$ & $\begin{array}{l}\text { A comparação da eficiência deste } \\
\text { método com a de uma técnica } \\
\text { amplamente utilizada indicou que o } \\
\text { novo método tem uma eficiência de } \\
\text { extração consideravelmente maior. } \\
\text { Para fibras e grânulos, um aumento de } \\
23 \% \text { e } 39 \% \text { foi observado; a eficiência } \\
\text { de extração do PVC aumentou em } \\
100 \%\end{array}$ & $\begin{array}{l}\text { Claesse } \\
\text { ns et al. } \\
(2013)\end{array}$ \\
\hline $\begin{array}{l}\text { Sedimento } \\
\text { úmido e } \\
\text { seco de } \\
\text { praia e água }\end{array}$ & $\begin{array}{l}\text { Secagem das amostras coletadas de sedimento úmido sob o } \\
\text { sol; peneiramento com diferentes aberturas de malhas até o } \\
\text { menor diâmetro; pesagem em balança analítica; análises em } \\
\text { estereomicroscópio para separação dos detritos sólidos e } \\
\text { análise quali-quantitativa em uma placa Petri com } \\
\text { manipulação manual com pinça e agulha para separação dos } \\
\text { MP encontrados; confirmação dos MP triados com teste do } \\
\text { ácido nítrico }\left(\mathrm{HNO}_{3}\right) \text { a } 65 \% \text {, usado para a dissolução rápida } \\
\text { de material biogênico; análise em estereomicroscópio para } \\
\text { confirmação definitiva do material não orgânico. }\end{array}$ & $\begin{array}{l}\text { Os resultados apresentados } \\
\text { constataram existência de MP. Em } \\
\text { relação aos sedimentos secos, } \\
\text { observou-se maior frequência de MP à } \\
\text { margem do rio, conferindo maior } \\
\text { evidência de aporte de MP } \\
\text { proveniente dos resíduos advindos da } \\
\text { água. } \mathrm{Na} \text { frequência do sedimento } \\
\text { molhado, verificaram-se maiores } \\
\text { valores na menor profundidade. }\end{array}$ & $\begin{array}{l}\text { Santos } \\
\text { et al. } \\
(2020)\end{array}$ \\
\hline Sal marinho & $\begin{array}{l}\text { Tratamento da amostra em solução de peróxido de hidrogênio } \\
\left(\mathrm{H}_{2} \mathrm{O}_{2}\right) \text {; dissolução da amostra pela adição de água filtrada; } \\
\text { filtração do sobrenadante no primeiro filtro; tratamento da } \\
\text { amostra em solução de peróxido de hidrogênio }\left(\mathrm{H}_{2} \mathrm{O}_{2}\right) \text {; } \\
\text { dissolução da amostra pela adição de água filtrada; filtração } \\
\text { do sobrenadante no primeiro filtro; digestão da solução } \\
\text { remanescente com } \mathrm{H}_{2} \mathrm{O}_{2} \text { a } 35 \% \text {; filtração do sobrenadante e } \\
\text { do remanescente contendo partículas minerais em segundo e } \\
\text { terceiro filtros; disposição dos filtros na placa de Petri; } \\
\text { secagem a } 40^{\circ} \mathrm{C} \text {; análises microscópicas e espectroscópicas } \\
\text { das características físicas como forma, tamanho e cor; } \\
\text { atribuição do tamanho de cada partícula; seleção manual das } \\
\text { partículas semelhantes a MP com o uso de uma micropinça; } \\
\text { análise para identificar os polímeros feita com um FT-IR; } \\
\text { estimativa do peso de partículas individuais de MP por } \\
\text { métodos matemáticos. Trinta e nove marcas diferentes de sal } \\
\text { produzidas em locais diferentes foram analisadas. Para } \\
\text { garantia de qualidade/controle de qualidade (QA/QC), } \\
\text { protocolos de controle rigorosos foram seguidos durante todo } \\
\text { o procedimento para tratamento e análise das amostras. }\end{array}$ & $\begin{array}{l}\text { Taxas relativamente altas de MP } \\
\text { foram investigadas em sais marinhos } \\
\text { produzidos em regiões asiáticas. Um } \\
\text { total de } 39 \text { marcas de sal produzidas } \\
\text { em locais geoespacialmente } \\
\text { diferentes, sendo } 28 \text { marcas de sal } \\
\text { marinho de } 16 \text { países / regiões em seis } \\
\text { continentes. De acordo com a } \\
\text { literatura publicada, essas taxas } \\
\text { exibiam correlações lineares } \\
\text { significativas com as emissões de } \\
\text { plástico encontradas em rios mundiais } \\
\text { com níveis de poluição de MP em suas } \\
\text { águas e no mar circundante. } \\
\text { Os resultados indicam que o sal } \\
\text { marinho pode ser um bom indicador da } \\
\text { magnitude da poluição por MP no } \\
\text { ambiente marinho que circunda a sua } \\
\text { produção. }\end{array}$ & $\begin{array}{l}\text { Kim et } \\
\text { al. } \\
(2018)\end{array}$ \\
\hline $\begin{array}{l}\text { Sais de } \\
\text { mesa }\end{array}$ & $\begin{array}{l}\text { Disposição dos sais de mesa em uma garrafa de vidro; } \\
\text { tratamento com peróxido de hidrogênio }\left(\mathrm{H}_{2} \mathrm{O}_{2}\right) \text { a } 30 \% \text {; } \\
\text { incubação a } 65^{\circ} \mathrm{C} \text {, e depois em temperatura ambiente; } \\
\text { flutuação e filtração com adição de água filtrada e } \\
\text { homogeneização da amostra; transferência da solução de sal } \\
\text { e do sobrenadante para filtros de nitrato de celulose por meio }\end{array}$ & $\begin{array}{l}\text { Foram detectadas } 550-681 \text { partículas } \\
/ \mathrm{kg} \text { em sais marinhos, 43-364 } \\
\text { partículas } / \mathrm{kg} \text { em sais de lago e } 7-204 \\
\text { partículas } / \mathrm{kg} \text { em sais de rocha/poço. } \\
\text { A abundância de MP em sais marinhos }\end{array}$ & $\begin{array}{l}\text { Yang et } \\
\text { al. } \\
(2015)\end{array}$ \\
\hline
\end{tabular}


de um sistema de vácuo; disposição dos papéis de filtro em placas de Petri limpas, com tampas; secagem em temperatura ambiente; transferência do material depositado no fundo das garrafas para outras placas de Petri; observação dos filtros em um estereomicroscópico e obtenção de imagens com uma câmera digital; avaliação visual para identificar os tipos e cores dos MP de acordo com as características físicas das partículas; seleção de algumas partículas aleatoriamente para verificação através de microespectroscopia de infravermelho com transformada de Fourier ( $\mu$-FT-IR). Quinze marcas de sais de mesa foram coletadas em supermercados na China. No processo, foram adotadas medidas rigorosas para evitar contaminação.

Fonte: Autoras (2020).

\section{Volume de amostras para identificação de MP}

A análise de MP pode demandar grandes volumes de amostra para se obter a representatividade, por causa das baixas concentrações desse material no meio analisado (LÖDER; GERDTS, 2015). Atualmente, encontram-se milhares de partículas de MP no meio ambiente, mas a falta de uma metodologia padronizada dificulta a sua identificação precisa. Existem alguns trabalhos na literatura com diferentes metodologias de análise. Há evidências de que o volume da amostra é um aspecto importante e que precisa ser bem definido. Conforme relatado por Prata e colaboradores (2020), o volume de amostra líquida utilizada nas metodologias disponíveis na literatura não é mencionado e, quando essa informação está disponível, os valores variam entre 10-2000 L. Nas análises realizadas por Ferrari (2019), foram utilizados $40 \mathrm{~L}$ de amostra para a realização dos estudos em efluentes brutos e tratados; Ziajahromi e colaboradores (2017) fizeram uso de diferentes volumes, que variaram entre 3-200 L; Wang e colaboradores (2017) usaram $20 \mathrm{~L}$ de amostra de água para análise. Entretanto alguns autores adotam volumes amostrais menores, como Gouveia (2018), que utilizou na sua metodologia 2 $\mathrm{L}$ de afluente tratado e $1 \mathrm{~L}$ de efluente bruto. Ao realizarem estudos com volumes menores, amostras entre 0,5-1,0 L, esses pesquisadores mostraram que é possível aumentar o número da amostragem usando recipientes de vidro, de fácil obtenção.

Para definir o volume ideal da amostra de manipueira, deve-se considerar a proporção de goma que será obtida após a decantação. Leonel e Cereda (2000) avaliaram que, para cada tonelada de mandioca processada, $257,7 \mathrm{~kg}$ de foi significativamente maior do que em sais de lago e sais de rocha/poço. goma são gerados. Em relação à manipueira, a literatura apresenta valores que variam entre 279$300 \mathrm{~L} / \mathrm{t}$, gerados a partir do beneficiamento de raízes de mandioca (ARAÚJO et al., 2014; FERREIRA; BOTELHO; CARDOSO, 2001). Portanto, a quantidade de goma será definida em função do volume de manipueira coletada.

\section{Contaminação cruzada}

Outros aspectos importantes que precisam ser considerados são as medidas de mitigação de contaminação cruzada. Devido à grande propensão à contaminação por MP, que podem estar presentes até mesmo no ar, durante o processo de análise é necessária a adição de medidas que minimizem essa possibilidade. No EFSA Panel on Contaminants in the Food Chain, em 2016, foram levantadas questões importantes que podem ser aplicadas na análise desse poluente. Por exemplo, um dos fatores cruciais nas determinações analíticas é garantir que as amostras não sejam contaminadas com MP do ar, roupas, equipamentos ou reagentes utilizados na análise (EFSA CONTAM PANEL, 2016). Nesse sentido, a orientação é manter cuidados que compreendem: minimizar, ao máximo, o contato com o ar por meio da cobertura de copos, garrafas, equipamentos de amostragem etc.; utilizar água e soluções filtradas; e manter uma limpeza meticulosa dos instrumentos (EFSA CONTAM PANEL, 2016). Além disso, no estudo realizado por Wang e colaboradores (2017), para evitar contaminação por partículas de MP durante a análise laboratorial, foram adotadas medidas preventivas que também podem ser aplicadas na determinação de MP em manipueira e goma de mandioca. Essas medidas consistem na lavagem dos materiais, três vezes, com água destilada, 
antes do seu uso; na utilização de papel alumínio a fim de evitar que a amostra fique descoberta; utilização de jalecos de algodão e luvas de nitrilo; e limpeza e inspeção do local de trabalho. Também foram realizados testes em branco do método, para verificar possíveis contaminações da água destilada e do ar no interior do laboratório.

Prata e colaboradores (2019) listam algumas regras para reduzir a contaminação cruzada de MP nas amostras, tais como: usar equipamentos de vidro e metal em vez de plástico; evitar o uso de têxteis sintéticos durante a amostragem ou manuseio de amostras, preferir o uso de jaleco 100\% algodão; limpar as superfícies com etanol $70 \%$ e toalhas de papel, lavar o equipamento com ácido seguido por água ultrapura; usar os produtos diretamente da embalagem e filtrar todas as soluções de trabalho; realizar testes em branco para controle de contaminação aérea; manter as amostras cobertas tanto quanto possível preferencialmente em uma capela de exaustão ou em unidade de cultura de algas, ou ainda, cobrindo o equipamento durante o manuseio e manipulá-las em salas limpas com circulação de ar controlada, com acesso e circulação limitados. Uma capela de exaustão pode reduzir $50 \%$ da contaminação, enquanto a medida preventiva de cobrir a amostra durante a filtração, digestão e identificação visual pode reduzir mais de $90 \%$ da contaminação (PRATA et al., 2019).

\section{Metodologia de detecção de MP na manipueira e goma de mandioca}

No estudo realizado por Hanvey e colaboradores (2017), foram avaliadas técnicas analíticas para detectar a presença de MP em sedimentos, que incluem quatro etapas principais: (1) Amostragem, (2) Extração, (3) Quantificação e (4) Garantia / controle de qualidade. Com base nesse estudo, a metodologia para detectar a presença de MP na manipueira e goma de mandioca deve obedecer às mesmas etapas.

\section{1) Amostragem}

De acordo com Löder e Gerdts (2015), amostras que apresentam baixas concentrações de MP demandam maiores volumes para detecção deste poluente. Por essa razão, nos primeiros testes deverão ser coletados $5 \mathrm{~L}$ de manipueira, e, caso não se consiga identificar os MP, o volume deverá ser ajustado até o limite de $20 \mathrm{~L}$.
Durante todo processo de análise é importante que as amostras fiquem, sempre que possível, tampadas, com o mínimo de contato com o ar, para evitar contaminação aérea. Na ausência de tampa, pode-se utilizar papel alumínio. Também deverá ser evitado qualquer utensílio de plástico.

As amostras de manipueira poderão ser coletadas em recipientes de vidros de 1,0-1,5 L com tampa e devem ser transportadas ao laboratório; posteriormente deve-se misturar as frações das amostras em um recipiente maior de vidro ou metal e agitar a mistura. Para separação das fases líquida (manipueira) e sólida (goma), a amostra deve ficar 12 horas em decantação. Esse período foi atribuído de acordo com o tempo utilizado em casas de farinhas tradicionais para obtenção da goma de mandioca. Após esse processo de separação, as amostras deverão ser acondicionadas para análise. Deverá ser coletada uma amostra do saco de náilon utilizado na prensa da casa de farinha. Caso não seja possível conseguir essa amostra, pode-se utilizar um saco de náilon similar.

Simultaneamente, serão preparadas em laboratório amostras com inserção de MP tanto para manipueira quanto para goma de mandioca, utilizando-se 0 material coletado. Esse procedimento consiste na adição de partículas trituradas do mesmo material utilizado no saco de náilon com concentrações e tamanhos conhecidos. Esses testes são necessários para verificar a eficiência da metodologia adaptada. Deve-se ter cuidado para que o microplástico produzido não contamine as outras amostras. As amostras deverão ser submetidas às etapas sequenciais descritas neste trabalho.

\section{2) Extração de microplástico}

\section{1) Extração de microplástico na goma de mandioca}

Após a separação e disposição em bandeja de metal, a goma deverá ser colocada na estufa a $60^{\circ} \mathrm{C}$ para secagem. Adotou-se essa temperatura em conformidade a estudos já realizados (Kim et al., 2018; Ziajahromi et al., 2017). Além disso, a temperatura de $60^{\circ} \mathrm{C}$ foi selecionada por estar dentro da faixa que não afeta as partículas de plástico. Segundo Munno e colaboradores (2018), as temperaturas devem ser controladas, iguais ou abaixo de $60^{\circ} \mathrm{C}$, eliminando-se picos durante as reações a fim de minimizar a perda de quaisquer 
MP presentes na amostra. As análises podem não ser representativas se as condições durante 0 teste removerem seletivamente alguns tipos de MP (MUNNO, 2018). Após secagem, a goma deverá ser resfriada e pesada em balança analítica.

Para extração de MP na goma de mandioca, será utilizada uma adaptação do método citado por Löder e Gerdts (2015), no qual a goma, após passar pelo processo de secagem, deverá ser misturada com uma solução salina concentrada e depois submetida à agitação até total evaporação do peróxido de hidrogênio (ZIAJAHROMI et al., 2017), o que permite a flutuação das partículas de plástico. As partículas mais leves flutuam ou permanecem em suspensão, enquanto que as partículas pesadas se depositam rapidamente. Depois, os MP são removidos do sobrenadante e depositados na placa de Petri, para secagem em temperatura ambiente e posterior análise no microscópio (LÖDER; GERDTS, 2015). Para préextração de MP da amostra sólida, Masura e colaboradores (2015) utilizaram uma solução salina. O mesmo procedimento foi realizado por Ferrari (2019), que utilizou $1,15 \mathrm{~g} / \mathrm{mL}$ de cloreto de sódio $(\mathrm{NaCl})$ na preparação da solução salina. $\mathrm{O}$ $\mathrm{NaCl}$ foi escolhido, pois apresenta boa disponibilidade, baixo custo e é ecológico (NUELLE et al., 2014). Para separar a parte líquida da parte sólida por densidade, Ziajahromi e colaboradores (2017) adicionaram a solução de iodeto de sódio (Nal) com concentração de 1,49 $\mathrm{g} / \mathrm{mL}$, uma vez que polímeros com uma ampla faixa de densidade irão flutuar em $\mathrm{Nal}$ (CLAESSENS et al., 2013; NUELLE et al., 2014). A mesma concentração da solução salina e da solução de iodeto de sódio serão adotadas na metodologia aqui proposta.

Visando resultados ainda mais precisos, será aplicado o método de coloração com solução de Rosa-Bengala, que colore partículas naturais, não plásticas. A superfície da placa será coberta com $5 \mathrm{~mL}$ de $0,2 \mathrm{mg} / \mathrm{mL}$ dessa solução por $5 \mathrm{~min}$ em temperatura ambiente (ZIAJAHROMI et al., 2017).

Os ensaios com a goma serão realizados em triplicata, com teste em branco, utilizando-se goma processada em fecularia, para o controle de contaminação aérea.

\section{2) Extração de microplásticos na manipueira}

Em virtude da alta concentração de matéria orgânica na manipueira, a literatura recomenda 0 uso de peróxido de hidrogênio com concentração de $30 \%$ para a sua remoção. Esse agente oxidante é eficiente e causa pouca ou nenhuma degradação dos polímeros (KIM et al., 2018; LÖDER; GERDTS, 2015; SANTOS et al., 2020; WANG et al., 2017; YANG et al., 2015). No experimento realizado por Ziajahromi e colaboradores (2017), durante o procedimento houve adição de $100 \mathrm{ml} / \mathrm{L}$ de peróxido de hidrogênio $\left(\mathrm{H}_{2} \mathrm{O}_{2}\right)$ nas amostras e posterior agitação a $60^{\circ} \mathrm{C}$. A cada hora, essas amostras foram verificadas visualmente até a completa evaporação do $\mathrm{H}_{2} \mathrm{O}_{2}$.

$\mathrm{Na}$ metodologia proposta, será utilizado o peróxido de hidrogênio para remoção da matéria orgânica, como realizado por Ziajahromi e colaboradores (2017), e um pré-tratamento com uma solução de cloreto de sódio $(\mathrm{NaCl}) \mathrm{com}$ concentração de $1,15 \mathrm{~g} / \mathrm{mL}$ (FERRARI, 2019). Para retenção das partículas presentes no fluido, será utilizado o processo de filtração com filtro de microfibra de porosidade $1,2 \mu \mathrm{m}$, sob vácuo (GOUVEIA, 2018). Após filtração, o filtro deverá ser colocado na placa de Petri e deverão ser aplicados $5 \mathrm{~mL}$ de $0,2 \mathrm{mg} / \mathrm{mL}$ de solução RosaBengala por $5 \mathrm{~min}$ em temperatura ambiente (ZIAJAHROMl et al., 2017).

Os ensaios com a manipueira serão realizados em triplicata. Para controle de contaminação aérea, durante o ensaio será realizado um teste em branco com água destilada, seguindo-se a metodologia proposta, sem o uso de peróxido de hidrogênio.

\section{3) Quantificação de microplásticos}

Após a extração, as amostras que foram colocadas nas placas de Petri serão analisadas no microscópio. Pode-se utilizar microscópio biológico e aplicar ampliações correspondentes a 128, 320, 640, 1280 e 2016 vezes, como foi feito por Cesa (2017), para identificação visual e contagem dos MP. Para garantir a melhor visibilidade dos MP, o microscópio deve ser acoplado a um dispositivo de captura de imagens digital (CESA, 2017). As características físicas como forma, tamanho e cor devem ser observadas para classificação e identificação da origem do poluente.

\section{4) Garantia / controle de qualidade}

Para confirmação dos MP, será aplicado nas placas de Petri o teste do ácido nítrico $\left(\mathrm{HNO}_{3}\right)$ $65 \%$, usado na dissolução rápida de material 
biogênico (SANTOS et al., 2020). Até mesmo nas placas que foram coradas com Rosa-Bengala. Posteriormente, deverá ser realizado 0 procedimento de quantificação de MP novamente, para a confirmação definitiva de sua presença.

Orientações gerais

Em caso do não fornecimento dos sacos plásticos por parte dos proprietários das casas de farinha, para o preparo de amostras com adição de MP em laboratório, pode-se utilizar um saco plástico similar;

Coletar informações adicionais sobre o período de tempo que o saco plástico foi utilizado e quantas vezes isso aconteceu.
A falta desses dados não impedirá a realização do experimento;

- Não utilizar utensílios plásticos;

- Quando possível, realizar os procedimentos na capela de exaustão;

- Sempre cobrir a amostra e realizar o procedimento o mais rápido possível;

- Lavar os recipientes e utensílios utilizados três vezes com água destilada;

- Utilizar jalecos de algodão e luvas de nitrilo;

- Realizar limpeza e inspeção do local de análise.

Para melhor entendimento do procedimento experimental, foi elaborado o Fluxograma 3.

\section{Fluxograma 3 - Etapas da metodologia adaptada para detecção de MP na manipueira e goma de mandioca}

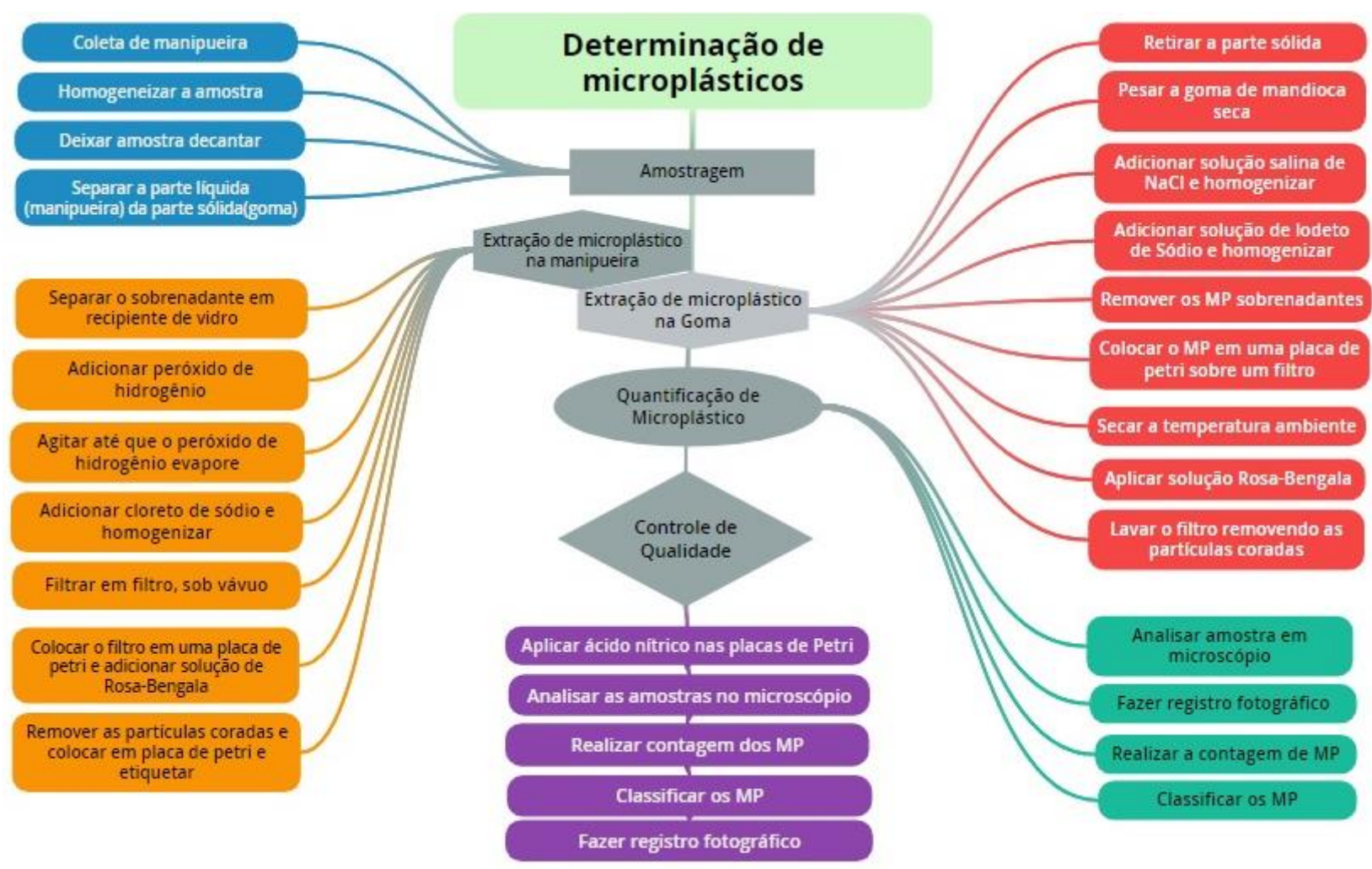

Fonte: Autoras (2020).

\section{CONCLUSÃO}

Nesta revisão, foram desenvolvidos dois métodos de detecção de MP, um para goma, com características sólidas, e outro para manipueira, resíduo líquido resultante do processo de beneficiamento da mandioca. As metodologias adaptadas para identificação de MP nas amostras consistem nas etapas de amostragem, extração, quantificação e garantia/controle de qualidade. As medidas de controle de contaminação cruzada estabelecidas, o teste em branco e testes com 
adição de MP produzidos nas amostras podem garantir maior credibilidade dos resultados $e$ possibilitar a determinação da eficiência dos métodos. Espera-se que, na testagem das metodologias propostas, os resultados possam ser validados por meio de ensaios interlaboratoriais $e$ que apresentem altas eficiências de detecção, contribuindo assim para avanços nas pesquisas nessa área e entendimento mais abrangente sobre a presença de MP em águas residuárias. Além disso, caso seja detectada a presença de MP, será necessário realizar novas pesquisas para avaliar a substituição de materiais plásticos utilizados no processamento da mandioca, visto que essa substituição traz benefícios, pois previne a possível contaminação, por MP, do meio ambiente e dos produtos resultantes do beneficiamento da mandioca. No entanto, devem-se considerar os custos envolvidos, a viabilidade para promover a substituição, além da conscientização dos proprietários das casas de farinha, devido aos aspectos culturais e sociais envolvidos nessa prática que atravessa gerações.

\section{AGRADECIMENTOS}

A Universidade Federal do Recôncavo da Bahia (UFRB) e ao Conselho Nacional de Desenvolvimento Científico e Tecnológico (CNPq), que apoiou financeiramente o presente trabalho.

\section{REFERÊNCIAS}

AKCELRUD, L. Fundamentos da Ciência dos

Polímeros. Barueri: Manole, 2007.

ALVAREZ, L. et al. Efectos de los microplásticos en el medio ambiente: Un macroproblema emergente.

Revista de Ciencia y Tecnología: RECyT, Posadas,

Argentina, v. 33, n. 1, p. 100-107, 2020. Disponível em: $<$ https://dialnet.unirioja.es/servlet/articulo?codigo $=7488$ 357>. Acesso em: 08 set. 2020.

ARAÚJO, N. et al. Quantificação da geração de resíduos em casas de farinha no estado da Paraíba.

Revista Monografias Ambientais, Santa Maria, RS, v. 13, n. 5, p. 3793-3799, 2014. Disponível em: <https://doi.org/10.5902/2236130814984>. Acesso em: 18 nov. 2020.

ARIENTE, M. et al. Competitividade na indústria de fécula de mandioca: estudo exploratório. Revista FAE, Curitiba, PR, v. 8, n. 2, p.53-60, jul./dez. 2005.

Disponível em:

<https://revistafae.fae.edu/revistafae/article/view/385>. Acesso em: 15 nov. 2020.
ARTHUR, C.; BAKER, J.; BAMFORD, H. (Org.). Proceedings of the International Research Workshop on the Occurrence, Effects and Fate of Microplastic Marine Debris. (September 9-11, 2008 University of Washington Tacoma, Tacoma, WA, USA). Silver Spring, MD: National Oceanic and Atmospheric Administration, 2009. p. 1-49. (Technical Memorandum NOS-OR\&R-30). Disponível em:

$<$ https://marinedebris.noaa.gov/sites/default/files/public ations-files/TM_NOS-ORR_30.pdf>. Acesso em: 08 set. 2020.

AUTA, H. et al. Growth kinetics and biodeterioration of polypropylene microplastics by Bacillus sp. And Rhodococcus sp. Isolated from mangrove sediment. Marine Pollution Bulletin, [s.I.], v. 127, p. 15-21, Nov. 2018. Disponível em:

<https://10.1016/j.marpolbul.2017.11.036>. Acesso em: 08 set. 2020.

BARANA, A. Avaliação de tratamento de manipueira em biodigestores fase acidogênica e metanogênica. 2000. 95 f. Tese (Doutorado em Agronomia - Área de Concentração em Energia na Agricultura) - Faculdade de Ciências Agronômicas, Universidade Estadual Paulista, Botucatu, SP, 2000. Disponível em: <http://hdl.handle.net/11449/101954>. Acesso em: 02 out. 2020 .

\section{BEZERRA, V. Farinha de Mandioca Seca e Mista.} Brasília, DF: Embrapa Informação Tecnológica, 2006. 44 p. (Agroindústria Familiar). Disponível em: <http://ainfo.cnptia.embrapa.br/digital/bitstream/item/71 134/1/AP-2006-farinha-mandioca-seca-mista.pdf>. Acesso em: 02 out. 2020.

BRANCO, M. Investigation on biological stabilization of toxic wastes from manioc processing. Program Water Tecnhology, Roma, Itália, v. 11, p. 51-4, 1979.

\section{CABELLO, C. Avaliação do substrato manipueira na biossíntese de ácido cítrico monitorada por computador. 1991. 88 f. Dissertação (Mestrado em Energia na Agricultura) - Faculdade de Ciências Agronômicas, Universidade Estadual Paulista, Botucatu, SP, 1991.}

CAMILI, E. Tratamento da manipueira por processo de flotação sem uso de agentes químicos. 2007, 78 f. Dissertação (Mestrado em Agronomia, Energia na Agricultura) - Faculdade de Ciências Agronômicas, Universidade Estadual Paulista, Botucatu, SP, 2007. Disponível em: <http://hdl.handle.net/11449/90446>. Acesso em: 02 out. 2020.

CEREDA, M. Resíduos da industrialização da mandioca no Brasil. São Paulo: Paulicéia, 1994. $174 \mathrm{p}$. 
CESA, F. Microplásticos têxteis: emissão de fibras sintéticas na lavagem doméstica. 2017. Dissertação (Mestrado em Ciências) - Programa de Pós-

Graduação em Têxtil e Moda, Escola de Artes,

Ciências e Humanidades, Universidade de São Paulo,

São Paulo, SP, 2017. Disponível em:

$<$ https://www.teses.usp.br/teses/disponiveis/100/10013 3/tde-19102017-

105403/publico/versaocorrigidaflaviacesa.pdf>. Acesso em: 07 set. 2020 .

CLAESSENS, M. et al. New techniques for the detection of microplastics in sediments and field collected organisms. Marine Pollution Bulletin, Amsterdã, Holanda, v. 70, n. 1-2, p. 227-233, 2013. Disponível em:

<https://doi.org/10.1016/j.marpolbul.2013.03.009>.

Acesso em: 04 out. 2020.

COLE, M. et al. Microplastic as contaminants in the marine environment: a review. Marine Pollution Bulletin, Amsterdã, Holanda, v. 62, n. 12, p. 25882597, 2011. Disponível em:

<http://dx.doi.org/10.1016/j.marpolbul.2011.09.025>.

Acesso em: 07 out. 2020.

CORRÊA, J. et al. Estudo sobre benefícios e desvantagens do uso do plástico e do papel em embalagens para sustentabilidade. Brazilian Journal of Production Engineering - BJPE, São Mateus, ES, v. 5(2), p. 77-87, 2019. Disponível em:

$<$ https://periodicos.ufes.br/bjpe/article/view/V05N02_8/p df>. Acesso em: 02 out. 2020.

COX, K. et al. Human consumption of microplastics. Environmental Science \& Technology, Washington, EUA, v. 53, n. 12, p. 7068-7074, 2019. Disponível em: <https://pubs.acs.org/doi/pdf/10.1021/acs.est.9b01517> . Acesso em: 02 out. 2020.

CREMONEZ, P. et al. Biodigestão anaeróbia no tratamento de águas residuárias de fecularias. Acta Iguazu, Cascavel, PR, v. 2, n. 2, p. 89-99, 2013. ISSN: 2316-4093. Disponível em:

$<$ http://e-

revista.unioeste.br/index.php/actaiguazu/article/view/83 97>. Acesso em: 11 nov. 2020.

DERRAIK, J. The pollution of the marine environment by plastic debris: a review. Marine Pollution Bulletin, Amsterdã, Holanda, v. 44, n. 9, p. 842-852, 2002. Disponível em: <https://doi.org/10.1016/S0025326X(02)00220-5>. Acesso em: 11 nov. 2020.

\section{EFSA PANEL ON CONTAMINANTS IN THE FOOD}

CHAIN. Presence of microplastics and nanoplastics in food, with particular focus on seafood. Efsa Journal, v. 14, n. 6:4501, 2016. Disponível em:

<https://efsa.onlinelibrary.wiley.com/doi/pdf/10.2903/j.ef sa.2016.4501>. Acesso em: 07 dez. 2020.
FEIDEN, A. Tratamento de águas residuárias de indústrias de fécula de mandioca através de biodigestor anaeróbio com separação de fases em escala piloto. 2001, $120 \mathrm{f}$. Tese (Doutorado em Agronomia/Energia na Agricultura) - Faculdade de Ciências Agronômicas, Universidade Estadual Paulista, Botucatu, 2001. Disponível em: <http://hdl.handle.net/11449/101835>. Acesso em: 11 nov. 2020

FERRARI, M. Avaliação da presença de microplásticos em esgoto sanitário do município de Campo Mourão - PR. 2019. Trabalho de Conclusão de Curso (Bacharelado em Engenharia Ambiental) Universidade Tecnológica Federal do Paraná, Campo Mourão, PR, 2019. Disponível em:

$<$ http://repositorio.roca.utfpr.edu.br/jspui/handle/1/1594 1>. Acesso em: 02 out. 2020.

FERREIRA, W.; BOTELHO, S.; CARDOSO, E. Uso da manipueira (tucupi) como fonte de nutrientes para o cultivo da mandioca: Comunicado Técnico n. 59, p.1-4. Belém, PA: Embrapa Amazônia Oriental, jun. 2001. Disponível em:

<http://ainfo.cnptia.embrapa.br/digital/bitstream/item/40 143/1/ComTec59.pdf>. Acesso em: 18 nov. 2020.

FIALHO, J.; VIEIRA E. Mandioca no Cerrado: orientações técnicas. 2 ed. Brasília, DF: Embrapa, 2013. Disponível em:

<http://ainfo.cnptia.embrapa.br/digital/bitstream/item/99 033/1/fialho-02.pdf>. Acesso em: 02 out. 2020.

GONZAGA, A. et al. Potencial de manipueira de mandioca (Manihot esculenta Crantz) no controle ce pulgão preto de citros (Toxoptera citricida Kirkaldy, 1907). Revista Brasileira de Agroecologia, Rio de Janeiro, RJ, v. 2, n. 2, p. 647, out. 2007. Disponível em: <https://ainfo.cnptia.embrapa.br/digital/bitstream/item/1 12651/1/6698-27293-1-PB.pdf>. Acesso em: 02 out. 2020.

GOUVEIA, R. Eficiência de remoção de microplásticos em quatro ETAR portuguesas. 2018. 99 f. Dissertação (Mestrado em Engenharia do Ambiente, Perfil Engenharia Sanitária) - Faculdade de Ciências e Tecnologia, Universidade Nova de Lisboa, Lisboa, PT, 2018. Disponível em: $<$ https://run.unl.pt/bitstream/10362/50893/1/Gouveia_20 18.pdf>. Acesso em: 02 out. 2020.

HANVEY, J. et al. A review of analytical techniques for quantifying microplastics in sediments. Analytical Methods, Burlington House, Londres, v. 9, n. 9, p. 1369-1383, 2017. Disponível em: $<$ https://pdfs.semanticscholar.org/4db9/1689266eddf98 69e759633a94811e166f6cf.pdf>. Acesso em: 02 out. 2020. 
HIDALGO-RUZ, V. et al. Microplastics in the marine environment: a review of the methods used for identification and quantification. Environmental

Science \& Technology, Washington, EUA, v. 46, n. 6, p. 3060-3075, 2012. Disponível em:

<http://dx.doi.org/10.1021/es2031505>. Acesso em: 07 out. 2020.

HOELLEIN, T. et al. Longitudinal patterns of microplastic concentration and bacterial assemblages in surface and benthic habitats of an urban river. Freshwater Science, Chicago, v. 36, n. 3, p. 491507, 2017. Disponível em:

<https://doi.org/10.1086/693012>. Acesso em: 04 out. 2020.

INSTITUTO BRASILEIRO DE GEOGRAFIA E ESTATÍSTICA. Levantamento Sistemático da Produção Agrícola. São Paulo: IBGE, 2019.

Disponível em:

<https://biblioteca.ibge.gov.br/visualizacao/periodicos/2 415/epag_2019_jan.pdf>. Acesso em: 04 out. 2020.

IVAR DO SUL, J.; COSTA, M. The present and future of microplastic pollution in the marine environment. Environmental Pollution, Amsterdã, Holanda, v. 185, p. 352-364, 2014. Disponível em:

<http://dx.doi.org/10.1016/j.envpol.2013.10.036>.

Acesso em: 07 out. 2020.

$\mathrm{KIM}$, J. et al. Global pattern of microplastics (MPs) in commercial food-grade salts: sea salt as an indicator of seawater MP pollution. Environmental Science \& Technology, Washington, EUA, v. 52, n. 21, p. 1281912828, 2018. Disponível em:

<https://doi.org/10.1021/acs.est.8b04180>. Acesso em: 03 out. 2020.

LAMO, P. R.; MENEZES, T J. B. Bioconversão das águas residuárias do processamento de mandioca para a produção de biomassa. Coletânea ITAL, v.10. p.114, Campinas, SP, 1979.

LEONEL, M.; CEREDA, M. Extração da fécula retida no resíduo fibroso do processo de produção de fécula de mandioca. Food Science and Technology, Campinas, SP, v. 20, n.1, p. 122-127, Apr. 2000. Disponível em: $<$ http://dx.doi.org/10.1590/S0101-

20612000000100023 >. Acesso em: 07 out. 2020.

LIMA, R. Tratamento de efluentes líquidos de unidades produtoras de farinha de mandioca. 2010. 76 f. Dissertação (Mestrado em Desenvolvimento de Processos Ambientais) - Universidade Católica de Pernambuco, Recife, 2010. Disponível em: <http://tede2.unicap.br:8080/handle/tede/599>. Acesso em: 18 nov. 2020.

LÖDER, M.; GERDTS, G. Methodology used for the detection and identification of microplastics - A critical appraisal. In: BERGMANN, M.; GUTOW, L.; KLAGES,
M. Marine Anthropogenic Litter. Berlim, Heildelberg, Alemanha: Springer, 2015. cap. 10, p. 201-227.

Disponível em:

$<$ https://link.springer.com/chapter/10.1007/978-3-31916510-3_8>. Acesso em: 02 out. 2020.

MAGNUSSON, K.; NORÉN, F. Screening of microplastic particles in and down-stream a wastewater treatment plant. IVL Swedish Environmental

Research Institute, Estocolmo, Suécia, p. 1-22, 2014. Disponível em: <https://www.diva-

portal.org/smash/record.jsf?pid=diva2\%3A773505\&dsw $\mathrm{id}=-8918>$. Acesso em: 03 out. 2020.

MAGRINI, A. Impactos ambientais causados pelos plásticos: uma discussão abrangente sobre os mitos e os dados científicos. Rio de Janeiro: E-papers, 2012.

MASURA, J. et al. Laboratory methods for the analysis of microplastics in the marine environment: recommendations for quantifying synthetic particles in waters and sediments. Silver Spring, MD, USA, 2015. Disponível em: <https://marinedebris.noaa.gov/sites/default/files/public ations-files/noaa_microplastics_methods_manual.pdf $>$. Acesso em: 07 out. 2020.

MICHAELI, W. et al. Tecnologia dos plásticos. Aachen, Alemanha: Blucher, 2018.

MODESTO JÚNIOR, M.; ALVES, R. Cultura da mandioca: Aspectos socioeconômicos, melhoramento genético, sistemas de cultivo, manejo de pragas e doenças e agroindústria. Brasília: Embrapa, 2016. 241 p.

MUNNO, K. et al. Impacts of temperature and selected chemical digestion methods on microplastic particles. Environmental toxicology and chemistry, Pensacola, Flórida, EUA, v. 37, n. 1, p. 91-98, 2018. Disponível em: <https://doi.org/10.1002/etc.3935>. Acesso em: 04 out. 2020.

MURPHY, F. et al. Wastewater treatment works (WwTW) as a source of microplastics in the aquatic environment. Environmental Science \& Technology, Washington, EUA, v. 50, n. 11, p. 5800-5808, 2016. Disponível em:

<https://doi.org/10.1021/acs.est.5b05416>. Acesso em: 03 out. 2020.

NAPPER, I. et al. Characterisation, quantity and sorptive properties of microplastics extracted from cosmetics. Marine Pollution Bulletin, Amsterdã, Holanda, v. 99, n. 1-2, p. 178-185, 2015.

NEVES, O. et al. Persistência do Cianeto e Estabilização do Ph em Manipueira. Revista Brasileira de Tecnologia Agroindustrial, Curitiba, Paraná, v. 8, n. 1, jan. 2014. Disponível em: 
<https://periodicos.utfpr.edu.br/rbta/article/view/1509>. Acesso em: 02 out. 2020.

NUELLE, M. et al. A new analytical approach for monitoring microplastics in marine sediments.

Environmental Pollution, Amsterdã, Holanda, v. 184, p. 161-169, 2014. Disponível em:

<https://doi.org/10.1016/j.envpol.2013.07.027>. Acesso em: 02 out. 2020.

OLIVATTO, G. et al. Microplásticos: Contaminantes de Preocupação Global no Antropoceno. Revista Virtual de Química, Niterói, RJ, v. 10, n. 6, p. 1968-1989, 2018. Disponível em:

<http://rvq.sbq.org.br/audiencia_pdf.asp?aid2=998\&no meArquivo=v10n6a16.pdf >. Acesso em: 02 out. 2020.

\section{PARIZOTTO, A. Eficiência de lagoas de} sedimentação na remoção de cargas orgânicas, nutrientes e coliformes totais em despejos industriais de fecularias. 1999. 113 f. Dissertação (Mestrado em Recursos Hídricos e Meio Ambiente) Universidade Estadual do Oeste do Paraná, Cascavel, Paraná.

PENICHE, L. O processo de trabalho na produção de farinha de mandioca no município de Rio Branco, AC: contribuições para vigilância em saúde do trabalhador. 2014. 96 f. Dissertação (Mestrado em Saúde Pública) - Escola Nacional de Saúde Pública Sergio Arouca, Fundação Oswaldo Cruz, Rio de Janeiro, 2014. Disponível em:

<https://www.arca.fiocruz.br/handle/icict/37414>. Acesso em: 18 nov. 2020.

\section{PIATTI, T.; RODRIGUES, R. Plásticos:}

características, usos, produção e impactos ambientais. Maceió: Edufal, 2005. 51 p. Disponível em: <http://www.usinaciencia.ufal.br/multimidia/livrosdigitais-cadernos-

tematicos/Plasticos_caracteristicas_usos_producao_e_ impactos_ambientais.pdf>. Acesso em: 02 out. 2020.

PINTO, P.; CABELLO, C. Tratamento de Manipueira de Fecularia em Biodiodigestor Anaeróbio para Disposição em Corpo Receptor, Rede Pública ou Uso em

Fertirrigação. Energia na Agricultura, Botucatu, SP, v. 26, n. 3, p. 127, 2011. Disponível em:

$<$ http://revistas.fca.unesp.br/index.php/energia/article/vi ew/278>. Acesso em: 02 out. 2020.

PRATA, J. et al. Methods for sampling and detection of microplastics in waterand sediment: a critical review. TrAC Trends in Analytical Chemistry, Amsterdã, Holanda, v. 110, p. 150-159, 2019. Disponível em: <https://doi.org/10.1016/j.trac.2018.10.029>. Acesso em: 02 out. 2020.

PRATA, J. et al. What Is the Minimum Volume of Sample to Find Small Microplastics: Laboratory
Experiments and Sampling of Aveiro Lagoon and Vouga River, Portugal. Water, Aveiro, PT, v. 12, n. 4, p. 1219, 2020. Disponível em:

<https://doi.org/10.3390/w12041219>. Acesso em: 05 out. 2020.

SANTOS, F. et al. Avaliação quali-quantitativa de microplásticos em sedimentos e na coluna d'água no balneário Canto das Águas-Glória/BA e balneário da Prainha-Paulo Afonso/BA. Brazilian Journal of

Development, Curitiba, PR, v. 6, n. 2, p. 8439-8453, 2020. Disponível em:

<https://doi.org/10.34117/bjdv6n2-233>. Acesso em: 07 set. 2020 .

SANTOS, G. et al. Avaliação espaço-temporal dos parâmetros de qualidade da água do rio Santa Rita (BA) em função do lançamento de manipueira.

Ambiente \& Água- An Interdisciplinary Journal of Applied Science, Taubaté, SP, v. 7, n. 3, p. 261-278, 2012. Disponível em:

$<$ https://www.scielo.br/pdf/ambiagua/v7n3/v7n3a20.pdf >. Acesso em: 02 out. 2020.

\section{SERVIÇO BRASILEIRO DE APOIO ÀS MICRO E PEQUENAS EMPRESAS-SEBRAE. Mandioca:} Farinha e Fécula. Brasília: Sebrae, 2012. 32p. Disponível em: <https://m.sebrae.com.br/Sebrae/Portal\%20Sebrae/UF s/RN/Anexos/Mandioca-(farinha-e-fecula).pdf>. Acesso em: 02 out. 2020.

SILVA, C. et al. A Degradação Ambiental Causada pelo Descarte Inadequado das Embalagens Plásticas:

Estudo de Caso. Revista Eletrônica em Gestão, Educação e Tecnologia Ambiental, Santa Maria, RS, v. 13, n. 13, p. 2683-89, 2013. Disponível em: <https://periodicos.ufsm.br/reget/article/view/8248>. Acesso em: 07 set. 2020.

SILVA, Í. et al. O saber-fazer farinha de mandioca: a tradição no processo produtivo, em Nazaré-BA.

Cadernos de Prospecção, Salvador, BA, v. 8, n. 2, p. 365, 2015. Disponível em:

<http://dx.doi.org/10.9771/s.cprosp.2015.008.041>. Acesso em: 07 set. 2020.

SILVA, P.; SILVA R. Influência dos microplásticos sobre populações bacterianas: uma revisão da literatura. In: CONGRESSO NACIONLA DE PESQUISA E ENSINO EM CIÊNCIAS, 4., 2019, Campina Grande. Anais [...] Campina Grande: Realize, 2019. Disponível em:

<http://editorarealize.com.br/artigo/visualizar/56929>. Acesso em: 07 set. 2020.

SILVEIRA, M. Farinhada: construção simbólica na reprodução da agricultura familiar. 2006. $114 \mathrm{f}$. Dissertação (Mestrado em Geografia) - Universidade Federal de Sergipe, São Cristóvão, SE, 2006. 
Disponível em: <https://ri.ufs.br/handle/riufs/5504>. Acesso em: 18 nov. 2020.

SOUZA, L. et al. (Org.). Processamento e utilização da mandioca. Brasília, DF: Embrapa Informação Tecnológica; Cruz das Almas: Embrapa Mandioca e Fruticultura Tropical, 2005. 547 p.

THOMPSON, R. et al. Lost at sea: where is all the plastic? Science, Washington, v. 304, n. 5672, p. 838, 2004. Disponível em:

$<$ https://www.researchgate.net/publication/8575062_Lo st_at_Sea_Where_Is_All_the_Plastic $>$. Acesso em: 07 set. 2020.

WANG, F. et al. Occurrence and distribution of microplastics in domestic, industrial, agricultural and aquacultural wastewater sources: A case study in Changzhou, China. Water Research, Amsterdã, Holanda, v. 182, 115956, 2020. Disponível em: <https://doi.org/10.1016/j.watres.2020.115956>. Acesso em: 04 out. 2020.

WANG, W. et al. Microplastics pollution in inland fresh waters of China: a case study in urban surface waters of Wuhan, China. Science of the Total Environment,
Amsterdã, Holanda, v. 575, p. 1369-1374, 2017. Disponível em: <https://doi.org/10.1016/j.scitotenv.2016.09.213>. Acesso em: 05 set. 2020.

WOSIACKI, G.; CEREDA, M. Valorização de resíduos de processamento da mandioca. Publicatio UEPG, Ponta Grossa, PR, v. 8, p. 27-43, 2002. Disponível em: $<$ http://publicatio.uepg.br/index.php/exatas/article/view/ 142/16>. Acesso em: 04 out. 2020.

YANG, D. et al. Microplastic pollution in table salts from China. Environmental science \& technology,

Amsterdã, Holanda, v. 49, n. 22, p. 13622-13627, 2015. Disponível em:

<https://doi.org/10.1021/acs.est.5b03163>. Acesso em: 04 out. 2020.

ZIAJAHROMI, S. et al. Wastewater treatment plants as a pathway for microplastics: development of a new approach to sample wastewater-based microplastics. Water research, Amsterdã, Holanda, v. 112, p. 93-99, 2017. Disponível em:

<https://doi.org/10.1016/j.watres.2017.01.042>. Acesso em: 04 out. 2020. 